УДК: 339.56: 338.48(477)

МЕТОДИЧНЕ ЗАБЕЗПЕЧЕННЯ ФОРМУВАННЯ ТА ПРОВЕДЕННЯ КОНТРОЛІНГУ ЗОВНІШНЬОЕКОНОМІЧНОЇ ДІЯЛЬНОСТІ ПІДПРИЄМСТВ ТУРИСТИЧНОГО ТА ГОТЕЛЬНОРЕСТОРАННОГО БІЗНЕСУ

DOI 10.30838/ P.ES.2224.290818.192.189

Разінькова М. Ю., к.е.н.

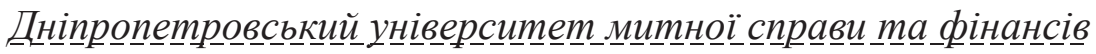
Дана стаття присвячена методичним передумовам створення та здійсненню контролінгу щодо зовнішньоекономічної діяльності компаній туристичної та готельно-ресторанної сфер. Встановлено складові, що обумовлюють рішення щодо імплементації контролінгу. Розроблено стадії всесторонньої методики імплементації системи контролінгу зовнішньоекономічних процесів компаній туристичного та готельно-ресторанного бізнесу. Дані стадії включають: відстеження усіх процесів компанії та їх стану, а також зовнішньоекономічної діяльності підприємства, оцінка стану сукупної діяльності компанії та їі зовнішньоекономічної діяльності, встановлення форм реалізації контролінгу зовнішньоекономічної діяльності організації, створення сукупності контрольованих показників, визначення еталонного рівня значень контрольованих показників. Також стадії включають: встановлення зовнішніх юридичних чинників змін у зовнішньоекономічних процесах компанії, оцінювання зовнішньоекономічної діяльності компанії, аналіз та регулювання заданого перебігу зовнішньоекономічних процесів підприємства, впровадження регулювання відхилення значень контрольованих індексів ЗЕДП, створення рішень в сфері менеджменту зовнішньоекономічної діяльності компанії, базуючись на змісті звітів.

Ключові слова: готельно-ресторанний бізнес, ЗЕД, контролінг, підприємства, туристичний бізнес.

UDC: $339.56: 338.48(477)$

\title{
METHODOLOGICAL SUPPORT FOR THE FORMATION AND CONTROL OF FOREIGN ECONOMIC ACTIVITY OF ENTERPRISES OF TOURIST AND HOTEL AND RESTAURANT BUSINESS
}

DOI 10.30838/ P.ES.2224.290818.192.189

Razinkova M., PhD in Economics

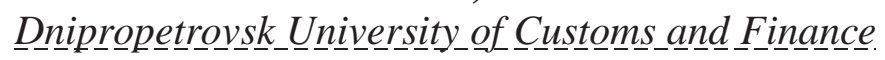
The article provides methodical support for the formation and implementation of controlling of foreign economic activity of enterprises of tourist and hotel and restaurant business. The components that determine the decision to implement controlling are

(C) Разінькова М. Ю., к.е.н., 2018 
established. The stages of comprehensive methodology for the implementation of the control system of foreign economic processes of tourist companies and hotel and restaurant business have been developed. These stages include: tracking all processes of the company and their status, as well as foreign economic activity of the enterprise, assessing the state of the company's total activity and its foreign economic activity, establishing forms for the control of the foreign economic activity of the organization, creating a set of monitored indicators, determining the reference level of values of the monitored indicators. Also, the stages include: the establishment of external legal factors of changes in the foreign economic processes of the company, evaluation of foreign economic activity of the company, analysis and regulation of the specified course of foreign economic processes of the enterprise, implementation of regulation of deviations of values of controlled indexes of foreign economic activity of enterprises, creation of solutions in the field of management of foreign economic activity of the company, based on the content of the reports.

Keywords: hotel and restaurant business, foreign trade, controlling, enterprises, tourist business

Актуальність проблеми. В сучасних умовах розвитку світових економічних взаємозв'язків процеси глобалізації включають у себе всі сектори господарства, не є винятком і глобальний ринок туристичних послуг. Внаслідок цього межі інтегрованості туристичних секторів та окремо взятих компаній різних держав зростають. В той же час посилюється конкурентна боротьба між державами, причиною якої $\epsilon$ диференціація туристичних потоків. Разом 3 тим, сьогодні в економіці розвинених держав має місце тренд до збільшення долі ринку туристичних послуг як у якості частки валового внутрішнього продукту, так і в якості частки структури споживання. Притаманним є швидкий розвиток новітніх технологій інформаційної сфери та електронної комерції у туристичній галузі. Дані процеси формують загрози для туристичних секторів держав із нижчою конкурентоспроможністю національних компаній, недостатньо відпрацьованими ринковими механізмами та недоліками державної політики у сфері туризму. Ці твердження справедливі для країн із перехідною економікою, серед яких перебуває також і Україна. Задля імплементації контролінгу в систему менеджменту зовнішньоекономічних процесів у компаніях туристичної та готельно-ресторанної сфери потрібно мати методичне підгрунтя, що включало б рекомендації стосовно організації та особливостей втілення певних контролінгових функцій згідно технологічних стадій. 
Аналіз останніх наукових досліджень. Питанням контролінгу в діяльності підприємств, які здійснюють зовнішньо-економічну діяльність присвячували свої праці провідні вітчизняні та зарубіжні науковці. Зокрема, Кармінський А. М. [3] досліджував методологічні та практичні засади побудови контролінгу в організаціях. Вагомий внесок у дослідження даної тематики також зробила Проскурніна Н. В. [5], яка досліджувала системи підконтрольних показників зовнішньоекономічної діяльності підприємства. Ставська Ю.В. [6] досліджувала особливості зовнішньоекономічної діяльності туристичних підприємств. Ціхановська В.М. [8] досліджувала тенденції розвитку світового ринку туристичних послуг в умовах посилення глобалізаційних процесів. Проте, на сьогодні існує необхідність комплексного дослідження методик здійснення контролінгу зовнішньоекономічної діяльності компаній туристичного та готельно-ресторанногосектору України. Це і обумовило вибір даної теми для статті.

Мета статті - розробити методичне забезпечення формування та проведення контролінгу зовнішньоекономічної діяльності підприємств туристичного та готельно-ресторанного бізнесу.

Виклад основного матеріалу. Зовнішньоекономічна діяльність туристичних підприємств розглядається як діяльність, що забезпечує надання різного роду туристичних послуг і продаж товарів туристичного попиту іноземним туристам у країні базування та вітчизняним туристам за кордоном для задоволення їх культурних, ділових та інших потреб й отримання прибутків. Важливим аспектом управління зовнішньоекономічною діяльністю туристичних підприємств $\epsilon$ адекватна, реалістична оцінка чинників та безпеки iï здійснення. Усі чинники, які впливають на характер та особливості зовнішньоекономічної діяльності туристичних підприємств, можна розділити на дві групи: зовнішні (зовнішні щодо туризму умови господарювання, середовище розвитку туристичного бізнесу) та внутрішні (внутрішні фактори, що безпосередньо пов'язані із туристичною діяльністю) [6].

Можна впорядкувати базу проблемні питання та вимоги щодо створення системи контролінгу та чинники, які ускладнюють впровадження контролінгу в умовах певної компанії. Базовими умовами, що $\epsilon$ основою для негайної імплементації системи контролінгу в компаніях туристичної та готельно-ресторанної сфери, $є$ наступні: 
- помітне зменшення або нівелювання темпів росту базових індексів ЗЕД та низькі індекси порівняно з конкурентами;

- оновлення завдань в умовах здійснення діяльності компанії туристичного та готельно-ресторанного бізнесу, що проводить зовнішньоекономічну діяльність, тобто глобального ринку;

- погана узгодженість завдань підприємства, що проводить зовнішньоекономічну діяльність;

- суттєві недоліки методів оперативного обліку та аналізу зовнішньоекономічної діяльності компанії, що веде до браку або нерелевантності даних аналіз при прийнятті рішень менеджменту відносно ведення зовнішньоекономічної діяльності;

- відсутність або повторення певних функцій в процесах компанії туристичної та готельно-ресторанної сфери;

- існування конфліктних положень при їх реалізації та прийнятті рішень менеджменту;

- підсилення позицій конкурентів при відсутності в них видимих переваг в якості послуг;

- недостатній рівень взаємодії структурних підрозділів у компаніях туристичного та готельно-ресторанного бізнесу.

Рішення про впровадження контролінгу повинне бути зваженим i обгрунтованим. В обгрунтуванні рішення про впровадження контролінгу можна виділити три компоненти: наявність економічних та управлінських проблем, доказ ефективності, доречності та своєчасності впровадження контролінгу зовнішньоекономічної діяльності підприємства [3].

У рамках останньої складової проводиться перевірка наявність у компанії, яка проводить зовнішньоекономічну діяльність, достатнього рівня ресурсів ( фінансових, людських та виробничих)

Виходячи із позитивних результатів імплементації контролінгу на окремо взятих підприємствах, технологію імплементації та здійснення контролінгу зовнішньоекономічної діяльності варто проводити згідно 3 методами, що включали б всебічну і чітку організацію та впровадження його у компанії.

Всеохоплюча методика імплементації контролінгової системи зовнішньоекономічної діяльності компанії туристичної та готельноресторанної сфери має містити в собі стадії, приведені на рис. 1.

Отже, розглянемо кожну стадію більш детально. 
1. Відстеження стану усіх процесів компанї та ї̈ зовнішньоекономічної діяльності. 3 метою своєчасної реакції на зміни у зовнішньому та внутрішньому середовищі, в рамках контролінгу зовнішньоекономічної діяльності компанії туристичної та готельноресторанної сфери необхідно здійснювати контроль великої кількості індексів, які відображають та дають оцінку процесам підприємства.

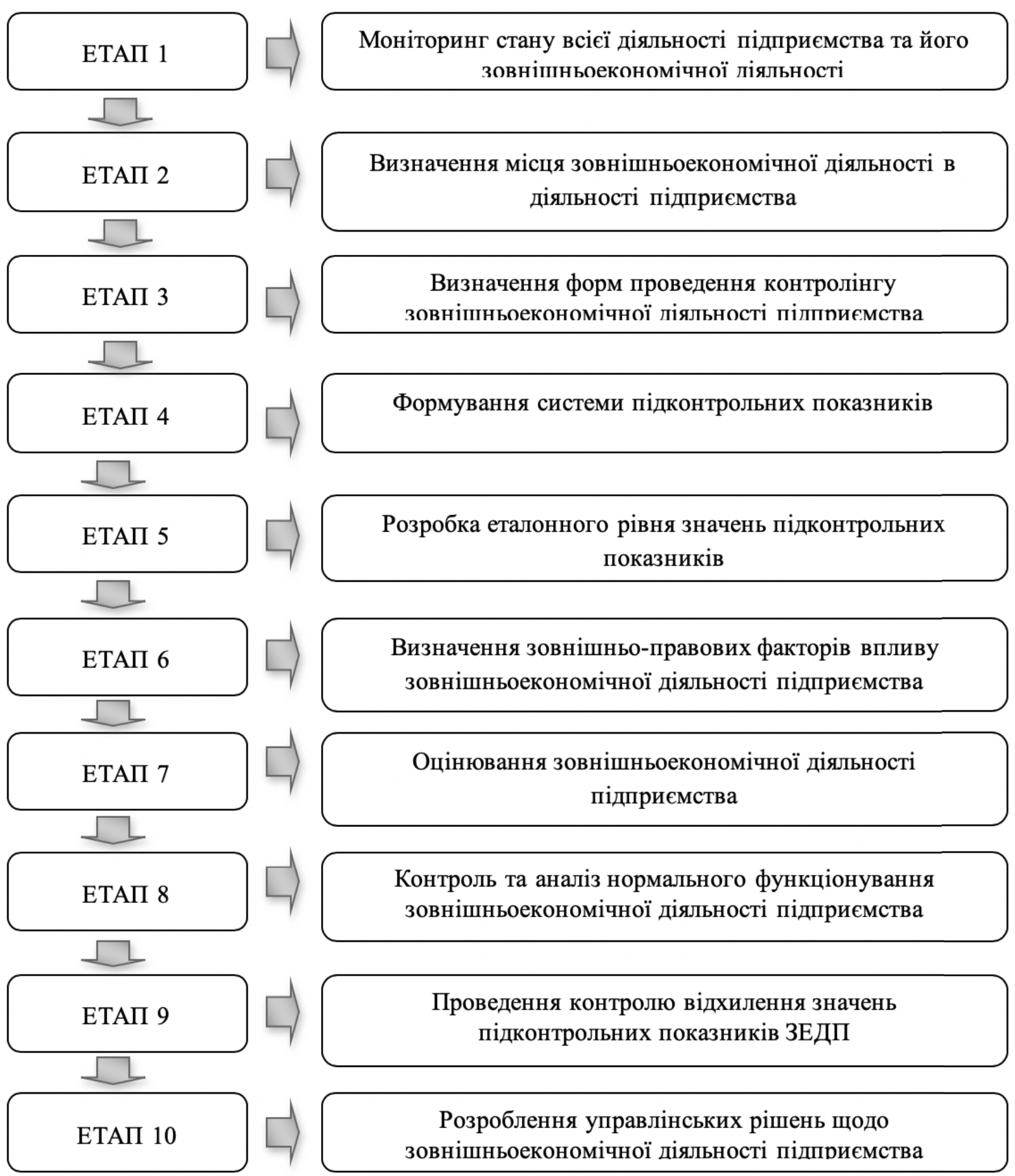

Pис. 1. Етапи комплексної методики впровадження системи контролінгу зовнішньоекономічної діяльності підприємства туристичного та готельноресторанного бізнесу Джерело: розроблено автором 
Найбільш раціональним напрямом організації такого регулювання $\epsilon$ організація спостереження - неперервного впорядкованого нагляду за показниками усіх середовищ (зовнішнього та внутрішнього) компанії, підбору і оцінки отриманих даних.

Почати відстеження стану зовнішньоекономічних процесів компанії варто 3 аналізу конкурентного середовища (передумов діяльності) та обраного ринку. Конкурентне середовище, в межах якого проводить діяльність компанія, неперервно зазнає змін. Тому потрібно стежити за релевантністю даних щодо виходу на ринок нових конкурентів, та стану уже наявних.

Згідно аналізу внутрішнього середовища компанії туристичної та готельно-ресторанної сфери передбачається окреслення проблемних питань, визначення слабких сторін та «вузьких місць» компанії, якими обумовлена розбіжність між еталоном та метою.

Аналіз зовнішнього середовища компанії обумовлений здебільшого загальним аналізом юридичних, соціально-політичних, економічних та інших зовнішніх чинників, що впливають на зовнішньоекономічні процеси підприємства. Це дає змогу вникнути у інфраструктуру ринку, в якій проводить діяльність підприємство, та об'єктивно оцінити можливості, слабкі та сильні сторони певного підприємства та його місце на ринку.

2. Визначення місия зовнішньоекономічних процесів в діяльності компанії, а точніше: питомої долі обсягу зовнішньоекономічних процесів в загальній структурі роботи підприємства, яке проводить зовнішньоекономічну діяльність. Внаслідок цього встановлюється міра та вага впливу змін в зовнішньоекономічних процесах компанії на ефективність ведення діяльності цієї компанії в цілому.

3. Встановлення форм здійснення контролінгу зовнішньоекономічної діяльності компанії.Обрання форми контролінгу зовнішньоекономічної діяльності компаніїгрунтуєтьсяна багатьох чинниках, включаючи: економічний стан підприємства, розумінняпотреби імплементації контролінгу з боку керівництва або власників компанії, розмір організації, рівень диверсифікації виробничих процесів, асортимент реалізованої продукції, кваліфікаціюменеджерських кадрів, конкурентний стан ринку, де проводить свою діяльність компанія. Фахівцямивиокремленонаступні форми контролінгу: оперативний, стратегічний, зовнішній, поточний та самоконтролінг.

\section{4. Створення системи контрольованих показників.}

Першою процедурою даного етапу $є$ теоретико-логічний аналіз показників, характеризуючих зовнішньоекономічну діяльність 
підприємства. Теоретично обгрунтовано та практично доведено, що контролінг зовнішньоекономічної діяльності рекомендується проводити за такими складовими: показники ефективності, показники динаміки змін та показники структурних зрушень $[1,5]$. До першої групи індексів включено індекс валютної ефективності експорту/імпорту, індекс економічної ефективності експорту/імпорту та індекс ефективності реалізації на локальному ринку продукції, яка була експортована. До другої групи індексів включено індекс ціни, індекс вартості, показник фізичного обсягу імпортованої або експортованої продукції, індекс кількості, показник здійснення планів експорту або імпорту та показник дотримання плану реалізації продукції на локальному ринку. До третьої групи показників включено: коефіцієнт питомої ваги певного типу експортованої послуги, індекс обсягну долі супутніх витрат у собівартості продукції, що експортується/експортується та індекс питомої ваги супутніх витрат в загальній структурі експорту.

Встановлення системи контрольованих індексів згідно кожного напрямку контролінгу зовнішньоекономічної діяльності базується на інформації фінансового та менеджерського обліку компаній, що проводять зовнішньоекономічну діяльність. Дана система $\epsilon$ первинною інформаційною базою моніторингу, що потрібна для майбутнього прогнозування агрегованих узгоджених абсолютних і відносних індексів аналізу зовнішньоекономічної діяльності компанії, що описують комплексні результати зовнішньоекономічної діяльності компанії у сфері структури, динаміки та дієвості змін зовнішньоекономічної діяльності.

5. Визначення еталонного рівня значень контрольованих індексів. Після того, як затверджено список контрольованих індексів зовнішньоекономічної активності компанії, формується необхідність визначення еталонного рівня значень контрольованих індексів по кожному з них. Дані рівні можуть визначатись як у абсолютних, так і у відносних величинах. Більше того, дані рівні можуть бути стабільними змінними за своїм типом (варіативні кількісні стандарти можуть бути застосовані при регулюванні індексів гнучких бюджетів, відпрацювання стандартів в умовах зміни облікової ставки, темпів інфляції, курсу національної валюти, валютних ставок тощо). Еталонами визначено задані стратегічні нормативи, індекси поточних бюджетів і планів, система державних або розроблених компанією нормативних документів i т. П. Еталони величини контрольованих показників визначаються шляхом аналізу економічних та стратегічних показників. 
6. Визначення зовнішніх юридичних чинників впливу зовнішньоекономічної активності компанї, яке передбачає відображення впливу правових змін, якими обумовлюється зовнішньоекономічна активність. Доведено на практиці, що вплив законодавчих поправок може мати як негативні, так і позитивні наслідки.

7. Оиінка зовнішньоекономічної активності компанії.

Створена система певних контрольованих індексів формує базу для впровадження ієрархічної системи окремих та інтегральних індексів зовнішньоекономічної активності.

Встановлення резервів активності та розвитку діяльності компанії туристичної та готельно-ресторанної сфери.

Під резервами компанії варто розуміти не використані (упущені) на цей момент перспективи розвитку або покращення господарської активності даної компанії, а саме зовнішньоекономічної, за рахунок збільшення обсягів виробництва та реалізації товарів, зменшення собівартості продукції, зростання суми прибутку і зростання рівня рентабельності, покращення фінансового стану, а також покращення контрольованих індексів компанії туристичного та готельно-ресторанного бізнесу, за рахунок встановлення латентних чинників зовнішньоекономічної активності та перспективного нівелювання їх впливу.

За типами резерви активності компанії поділяють на внутрішні та зовнішні. Виходячи з цього, внутрішні резерви поділяються на інтенсивні та екстенсивні.

Екстенсивні резерви являють собою збільшення обсягів використовуваних в процесі надання послуг ресурсів (трудових ресурсів, основних фондів), а також збільшення часу використання трудових ресурсів та основних фондів, і крім того, усунення причин непродуктивного використання всіх названих видів ресурсів. Інтенсивні резерви полягають у тому, що підприємство може 3 незмінною кількістю використовуваних ресурсів виготовити більший обсяг продукції, або виготовити той же обсяг продукції з меншою кількістю використовуваних ресурсів. Основним напрямком використання інтенсивних резервів $є$ використання досягнень науково-технічного прогресу [2].

Зовнішні резерви можуть поділятись за класифікацією на народногосподарські, регіональні та галузеві. До цієї категорії можна включити перерозподіл отриманих коштів між певними секторами економіки, а також між деякими регіонами країни.

8. Контроль та аналіз заданої активності зовнішньоекономічної діяльності компанії. 
Прогнозування та планування значень контрольованих індексів, беручи за основу дійсні умови проведення та розвитку зовнішньоекономічної активності підприємства.

Визначення розмірів різниці між фактичними та еталонними (нормативними) значеннями величини контрольованих індексів зовнішньоекономічної діяльності проводиться як у відносних, так і в абсолютних індексах. Так, як кожен індекс присутній в контрольних звітах виконавців, на даному етапі він також агрегується в межах компанії в цілому. В той же час, по відносних індексах усі відхилення відносяться до трьох груп: позитивні відхилення, «допустимі» (негативні) відхилення, «критичні» (негативні) відхилення.

3 метою здійснення такого розподілу на кожному підприємстві мусить бути задано критерій «критичних» відхилень, який може відстежуватись хронологічно по контрольним періодам. В якості критерію «критичного» відхилення можна обрати відхилення розміром від 20 і більше відсотків згідно декадного (тижневого) контрольного періоду; від 15 і більше відсотків в місячному зрізі; від 10 і більше відсотків в масштабі кварталу. Критерії встановлюються згідно до вагомості зовнішньоекономічної активності для компанії та питомої частки обсягу зовнішньоторговельного обороту на компанії.

Встановлення базових чинників відхилень дійсних результатів контрольованих індексів від визначених еталонних рівнів здійснюється по підприємству в цілому і по окремим секторам (типу послуг, державам або організаціям, 3 якими взаємодіє компаніi). У ході цього аналізу виокремлюються i досліджуються індекси контролінгу зовнішньоекономічної активності підприємства, що демонструють критичні відхилення від заданих значень, поточного плану і кошторису. По кожній «критичній» розбіжності, а (при необхідності) i по менш вагомим величинам відхилень індексів зовнішньоекономічної активності підприємства, мають бути встановленні причини, які їх обумовили. У ході проведення цього аналізу по підприємству в цілому застосовуються відповідні розділи контрольних звітів виконавців.

9. Здійснення контролю розбіжності значень контрольованих індексів ЗЕДП передбачає встановлення контрольних періодів по усіх напрямках контролінгу зовнішньоекономічної активності i кожній групі контрольованих індексів. Уточнення контрольного періоду згідно напрямків контролінгу i групам індексів обумовлюється «нагальністю реагування», що потрібна для прийняття рішення менеджменту та ефективного керування компанією, що проводить зовнішньоекономічну 
діяльність. Беручи до уваги цю стадію, виокремлюють такі контрольні звіти: тижневий (декадний), місячний та квартальний.

10. Розроблення рішень менеджменту відносно зовнішньоекономічної активності компанії за результатами звітів.

Якщо утворені розбіжності, що не виходять за рамки дозвільних нормативів, $є$ позитивними змінами, керівництво компанії може не вживати жодних мір, тому що дійсний стан активності компанії, що проводить зовнішньоекономічну діяльність, задовольняє менеджмент.

У разі, якщо розбіжності мають критичний розмір або некритичні розбіжності мають тренд до збільшення, то, за допомогою встановлення причинно-наслідкових зв'язків, менеджмент підприємства приймає план управлінських дій відносно нівелювання наявних розбіжностей, а саме: встановлює причини розбіжностей, визначає відповідність між причинами та типами відхилень; призначає відповідальних та приймає рішення, що дають можливість уникнути небажаних розбіжностей в перспективі).

Висновки. Таким чином, базуючись на запропонованій методиці, обумовлюється науково-аналітична основа рішення менеджменту щодо порядку дій, що направлені на підтримку факторів ефективної активності компаній туристичного та готельно-ресторанного бізнесу. Імплементація системи контролінгу зовнішньоекономічної активності компанії дає можливість помітно підвищити ефективність управлінського процесу на підприємстві загалом, що, у свою чергу, приведе компанію до отримання додаткового прибутку, який може бути направлений на подальший розвиток.

\section{СПИСОК ВИКОРИСТАНИХ ДЖЕРЕЛ:}

1. Вічевич А. М. Аналіз зовнішньоекономічної діяльності : Навч. посіб. - 2-ге видання, перероб. та доп. / А. М. Вічевич, О. В. Максимець. - К. : «Видавничий дім «Професіонал», 2009. - 216 с.

2. Войтловский Н. В. Комплексный экономический анализ предприятия : Учебник для вузов / Н. В. Войтоловский, А. П. Калинина, И. И. Мазурова. - СПб. : Издательский дом «Питер», 2010. - 576 с.

3. Карминский А. М. Контроллинг в бизнесе. Методологические и практические основы построения контроллинга в организациях / А. М. Карминский, Н. И. Оленев, А. Г. Примак, С. Г. Фалько. - М. : Финансы и статистика, 2002. - 256 с.

4. Малярець Л. М. Визначення впливу законодавчо-правових факторів на ефективність зовнішньоекономічної діяльності підприємства / Л. М. Малярець, Н. В. Проскурніна // БІЗНЕС ІНФОРМ. - Харків : ХНЕУ, 2011. - № 11(406). - С. 129-131. 
5. Проскурніна Н. В. Обгрунтування системи підконтрольних показників зовнішньоекономічної діяльності підприємства / Н. В. Проскурніна // Управління розвитком. - Харків : ХНЕУ, 2011. - № 5(102). - С. 187 - 189.

6. Ставська Ю.В. Особливості зовнішньоекономічної діяльності туристичних підприємств / Ю.В. Ставська // Глобальні та національні проблеми економіки. 2017. - Вип. 19. - С. 46-49

7. Сорока I. Сучасні тенденції міжнародного ринку туристичних послуг / I. Сорока // Актуальні проблеми міжнародних відносин. - 2012. - Вип. 111. - С. 266-273.

8. Ціхановська В.М. Тенденції розвитку світового ринку туристичних послуг в умовах посилення глобалізаційних процесів / В.М. Ціхановська, С.Я. Ковальчук // Глобальні та національні проблеми економіки - 2015. - № 7. - С. 86-89 [Електро- нний ресурс]. - Режим доступу : http://global-national.in.ua/ issue-7-2015/15-vipusk-7-veresen-2015r/1189-tsikhanovskav-m-kovalchuk-s-ya-endentsiji-rozvitku-svitovogo-rinkuturistichn ikh-poslug-vumovakh-posilennya-globalizatsijnikhprotsesiv 